TRAMES, 2008, 12(62/57), 3, 287-298

\title{
FIGURES OF (TRANS-) NATIONAL RELIGIOUS MEMORY OF THE ORTHODOX SOUTHERN SLAVS BEFORE 1945: AN OUTLINE ON THE EXAMPLES OF SS. CYRIL AND METHODIUS
}

\author{
Stefan Rohdewald \\ Universität Passau
}

\begin{abstract}
Analyzing figures of national religious memory of the orthodox Southern Slavs, we focus on the changes concerning the temporal horizon, the contents, carried and brought to mind by the figures, and the forms of collective identity that were produced or reinforced by these realisations in their specific social or 'national' situation. This essay outlines as examples changes in the veneration of Cyril and Methodius, and shows how they became, within the framework of national movements, important crystallisation points for national identities, although initially their traditional veneration was to a high degree Slavonic, or transnational. National identity was more and more isolated from the transnational context - until then reference to the other Slavonic peoples served only to demonstrate the historic importance of their 'own' nation's mission. One can distinguish more or less clearly a secularisation of the saints in the 19th century, within the context of historicism and nationalism; while during the 1930s and World War II they served the sacralisation of nationalism.
\end{abstract}

DOI: $10.3176 /$ tr.2008.3.04

Keywords: Cyril and Methodius, Serbia, Bulgaria, Macedonia, figures of national religious memory

\section{Introduction}

The analysis of lieux de mémoire, or places of memory, is - in the eyes of the historian - still a relatively new approach. Although its origins lie in the works of Maurice Halbwachs, it was only applied later by Pierre Nora, and subsequently in Germany by Etienne François and Hagen Schulze (Echterhoff and Saar 2002). Within this concept, places of memory are to be understood metaphorically - they are not confined to physical places, but include personalities, events, buildings and 
memorials, institutions and terms. Such places of memory exist in the production and reproduction of social groups sharing the remembrance. They are "long living points of crystallisation of collective memory and identity. They are embedded in societal, cultural and political practices, and they change inasmuch as the ways of their perception, reception, use and transmission change" (François and Schulze 2001:18). Jan Assmann (1997) writes about 'figures of memory', and defines them as "culturally formed, societally binding "images of memory" - a term used already by Halbwachs. Assmann prefers the term 'figure', because it means not only iconographic shaping, but narrative, too - alluding to figures of speech. 'Figures of memory' have, with Jan Assmann, a 'specific relationship to time and space' as well as to a social group. According to him, 'cultural memory concentrates on fixed points in the past'. The past 'levitates and fixates' into 'symbolic figures'. In the process of remembrance, history is said to become 'a reality as a normative and producing power' (Assmann 1997:52). Yet Assmann's sharp separation between dynamic 'communicative memory' (which refers to the recent past and communication with living witnesses) and the long term, less flexible 'cultural memory' must be questioned. While Halbwachs stressed the dynamics of reproduction, Assmann's conception of a primarily religious 'cultural memory' is more static. Yet change in 'mythical history' (Smith 1999) in repeated narration is not to be underestimated, but rather has to be of primary interest (Flacke 1998). Seeing figures of memory as possibly 'invented traditions' (Hobsbawm and Ranger 1983) to foster national 'imagined communities' (Anderson 1991), one has to be very sceptical about any claims of continuity and homogeneity.

Lieux de mémoire are most often analysed in a national context, and seldom, until lately, in a transnational setting. For the new cultural history of nationalism, the construction, popularisation and cultural medialisation of national selfperception is pivotal. ${ }^{1}$ Yet so-called national saints, or Christian religious figures of memory, have so far mostly been analysed for the late medieval ages and early modern period, while only a few works focus on their role in the 19th and 20th centuries. When Nationalism is analysed as 'secular religion', the term 'religion' is used in an analytical and abstract way. Yet it is my intention to look for expressively Christian elements in nationalism (Steigmann-Gall 2004:390-93). ${ }^{2}$

Working with these concepts, the perception of the individuals themselves (and thus their words and sentences) remains of determining significance. I concentrate on national religious figures of memory in nominally orthodox societies to investigate whether the latter developed a special relationship between Christian religion and nationalism. Religious history and cultural history are thus central aspects of political history. In a further step, which does not lie within the scope of this study, the results have to be compared to the evolving research on national

\footnotetext{
On Macedonia, Bulgaria and Serbia, separately: Weber 2006, Anzulovic 1999, Brown 2003.

On religion and nationalism in Eastern Europe: Maner and Schulze-Wessel 2002. Also: Smith 2003.
} 
saints in western European modern societies. Only then is the project able to adapt, confirm or refute the often-asserted thesis of an especially close relationship between church and nation in Eastern Europe - particularly between nationalism and the Orthodox church.

For my project, 'Figures of National Religious Memory of the Orthodox Southern Slavs until 1945', only those phenomena which were important in the political discourse of the Slavic dominated pre-modern societies, or those which became relevant during the national movements in and after the 19th century, are discussed. Religious figures of memory of smaller regional groups are only analysed if they played a trans-regional role at some point in time. The project focuses namely on Saint Sava (Aleksov 2003), the Kosovo-myth (Emmert 1990, Vucinich and Emmert 1991, Nitsche 2003), the brothers Cyril and Methodius, Kliment Ohridski, Ivan Rilski and several monasteries.

Thus, the manner and phases of change from medieval religious 'memoria' (Oexle 1995) to nationally reinterpreted references to historical epochs and key figures have to be analysed. We must focus on the changes concerning the temporal horizon, the contents, carried and brought to mind by the figures, and the forms of collective identity that were produced or reinforced by these realisations in their specific social or 'national' situation. As in all national contexts, figures of memory, or the ideologies they represent, were used in specific situations to [re]negotiate their value and importance in relationship to other ideologies, especially in the context of societal crises, such as wars.

By concentrating on religious figures of memory and the change in the practices of worshipping them we can ask, whether the formation of important elements of national identity of the orthodox Southern Slavs can be put into a broader context that transgresses boundaries of local national remembrance: Can the specific figures of memory be understood as being connected to, or part of, a transnational or South Eastern European repertoire of religious remembrance of the orthodox Southern Slavs? After all, the comparative exploration of the instrumentalisation and mediation of these figures of memories and their interaction should constitute a way to establish the correlation between the development of Serbian, Bulgarian and Macedonian national identities, which evolved in a very close context of regional competition.

Moreover, Figures of National Religious Memory of the Orthodox Southern Slavs, as part of Serbian, Bulgarian and Macedonian history, offer an excellent opportunity for a case study of 'entangled history', or histoire croisée: concentrating on interdependency, linkage and interconnectedness, a 'pluralisation of perspectives' and a new reflection of national perspectives are central to these concepts. 'Transnational' cultural processes are analysed as having a 'logic of their own', challenging national contexts (Werner \& Zimmermann 2002:635). 'Global history' is often conceived as the history of distant relationships - yet these relationships should be analysed between smaller entities and regions as well. These questions need not be confined to the 19th and 20th centuries. 
'Local' cults of saints and the patterns of identity of dynasties and ruling groups, connected with them in medieval times, reached only a very limited number of people (Eastmond, 2003). On the other hand, some saints were worshipped not only by one ethnic group or within one dynastic realm. In modern times, even the so-called national saints of national movements had spheres of influence, which neglected the boundaries of the projected nations. Namely, Cyril and Methodius were worshipped not only by Bulgarians, but by Serbians and then by Macedonians, too. To some degree, the same is true for Kliment Ohridski and the Bulgarian Ivan Rilski. The Serbian saint Sava, on the other hand, remained more exclusively in a national context. Especially in the territorial rivalry between Bulgaria and Serbia over Macedonia, one may observe a competition over the national identity of local groups, in which religious figures of memory played a decisive role.

This paper will concentrate on the examples of the remembrance of Cyril and Methodius in the 19th and 20th centuries. Out of the vast volume of publications by clerics, professional historians, teachers and journalists I will pick some examples that can be helpful in distinguishing phases of culture of remembrance. It has to be kept in mind that remembering Cyril and Methodius is a principal European practice - the brothers have been declared co-patrons of Europe by Pope John Paul II.

\section{Beginnings in the Middle Ages}

The medieval beginnings must be briefly summarised. Cyril (ca. 826/827-869) and Methodius (ca. 815-885) grew up in a bilingual situation in Salonica and became the most important missionaries of the Slavs for the Orthodox Church. While their missionary actions concentrated on Great Moravia, their followers began later to operate in the Bulgarian realm. Both were venerated in religious texts as 'Apostles of the Slavs' or 'first Educators and Teachers of the Slavonic people'. In several early texts, no ethnic groups within the Slavs are distinguished; there is writing, for example, about the 'manifold tribes of the Slavonic people.' Their most important function was that of traditional Christian Saints: they were imagined as living personalities who could be asked to pray for the support and forgiveness of God. Although there was a 'Bulgarisation' of their veneration during the second medieval Bulgarian Empire (Češmedžiev 2001:79-110, Polyviannyj 1999, Kämpfer 1994, Lis 2004), a fundamental change in their remembrance only occurred much later.

\section{Revitalisation, secularisation and nationalisation in the 'long' 19th century}

Beginning with works such as the 'Slavenobulgarian History' by the Monk Paisij, and later, influenced by the Czech, Russian and panslavic romantic revitalisation of the 'Slavonic Apostles', the brothers became, in the middle of the 
19th century, a medium for the imagination of a homogenous Bulgarian nation. At this time, the brothers became patrons of more and more Bulgarian schools. In the framework of the first celebrations in honour of the brothers, and their description in the new medium of newspapers, the contents and the function of the discourse about them changed from having a traditional religious character to displaying a national character. In 1969, Bonju Angelov showed how their veneration stopped having a purely ecclesiastical meaning, and acquired another: writing and interpreting from a socialist perspective, he underscored the significance of the feasts for the Enlightenment, the national 'Rebirth', and the 'national liberation' of Bulgaria (Angelov 1969:127). Celebrations for School patrons in other national discourses provided the cultural templates to organise the feasts - namely, the example of the Serbs was important: they had been institutionalizing Saint Sava as Patron of the Serbian Schools during the first half of the 19th century. The celebrations of Cyril and Methodius soon became an important means for imagining a Bulgarian nation, living in apparently ethnically homogenous Bulgarian cities - even if these cities were basically, without exception, multiethnic. For teachers, and then for clerics, too, Cyril and Methodius became the means by which the perception of Bulgarians as a distinct historical ethnic group was promoted. Their contribution to the imagined medieval national history was interpreted in a religious as well as in a cultural historical way and became the rhetorical foundation and legitimisation of the contemporary, modern 'Rebirth'. The narrative soon became the historical example and image of the "national Renaissance', which was eagerly promoted. In this new interpretation of the Brothers, there was now doubt about their Bulgarian origin. In 1885, only some years after the establishment of a sovereign Bulgarian Princedom, Methodius's death one thousand years ago was celebrated with particular enthusiasm. After the Bulgarian Metropolitan, Prince Aleksandăr himself honoured them with a speech in parliament. Here he imagined the brothers as 'our gleaming double star', for which one had to thank the 'Genius of the Bulgarian people'. Talk of a 'holy testament' of the brothers gave the temporal horizons of the discourse about them a not merely current, but also future meaning (Xiljadogodišnij jubilej 1885:29). To enforce the new state, it had to get as much historical legitimisation as possible. In the words of Vasil Drumev, Prime Minister of Bulgaria in 1879-80 and Metropolitan of Tărnovo after 1884, Cyril and Methodius had been, alluding to Herder, inventors of the reformation, because they used the vernacular language as liturgical language. Contradicting contemporary Western European assumptions about the backwardness of the Balkans in the 19th century, Cyril and Methodius were described as innovative historical forerunners of the reformation in England and Germany, which were seemingly leading global progress. Thus, as the Prime Minister and leading churchman claimed, Cyril and Methodius could secure the Bulgarians 'as an historical people' an 'honoured place in human history' (Drumev 1885:5). Although representatives of the still small Bulgarian intellectual elite venerated the brothers in 1885 as Slavonic Apostles in a transnational way, their connection to a Bulgarian national meaning was already dominant. It must be 
underscored that this jubilee, as well as the annual feast of the "national School Day' on their Saints' day, were seen explicitly in an international setting: the reference to practices of the promotion of the national identities of Serbs, Greeks and Russians gave legitimacy and was decisive for the direction in which Bulgarian social practices of identity were developed.

Within the Serbian context (Durković-Jakšic 1986), the remembrance of the brothers was changed by the concept of modern nationalism, too. Concentrating in this chapter on orthodox discourses, it can be only hinted to the broader context, namely catholic Slovenian and Croat discourses, i.e. the veneration of Cyril and Methodius by the Bishops Anton M. Slomšek and Josip Juraj Strossmayer (Grivec 1927:144-146; Stroßmayer 1881). When, in 1863, the 'Association of Serbian Philology' commemorated the death of Cyril a thousand years earlier, its president, Dimitrie Matić, was talking explicitly about the goal of the creation of an ethnically 'pure' Slavonic people: with God's help, there should be a 'whole Slavonic people with purely Slavonic faces and of purely Slavonic character' (Hiljadugodišnja 1863:4). This conception of an overall Slavonic identity was connected by Cyril and Methodius to a sacral context. This transnational, overall Slavonic dimension remained, in the commemoration of the brothers by representatives of the Serbian elite, more important than a Serbian interpretation. But in Serbia as well as in Bulgaria, the more and more secularised commemoration of the brothers was used by the leaders of the national movements to give the new state a national history, conceived within modern historicism, and an honoured place in European and universal history.

In the context of the Macedonian region (Polenakovik 1963, Balabanov 1988, Trajanovski 1995), in the initial stage of the change in the 19th century, the emergence of an overall Slavonic discourse of remembrance of the brothers can be observed as well. A letter to the editor of the Bulgarian newspaper Independence published in Bucharest, reported the celebrations in honour of the brothers in May 1873 in Salonica. The author wished within this framework that the city should become the 'centre of the Slavonic people', in distinction from the Greeks (Bukurešt 1873:273). Within the reference to Cyril and Methodius, it was not even possible to consider that the city actually had a Jewish majority. Yet soon, this transnational Slavonic horizon became less important in this case than a Bulgarian national interpretation of the brothers. Salonica, as the so-called 'cradle of the two Saints', was claimed to have enormous significance not only for the Bulgarian nation, but also for the whole world. The emerging social and rhetorical practices connected to the feast of the Saints were very important frames for the promotion and social broadening of a Bulgarian consciousness.

These commemorations of the brothers in Ottoman Vardar-Macedonia were observed with concern by Serbian intellectuals, and motivated them to analogous steps. The Bulgarian propagation of Cyril and Methodius in this region was criticised by Serbian intellectuals. Milojko Veselinović, as teacher and then as Vice-Consul, was one of the most active members, and, in 1886, one of the founders of the Saint Sava Association, which had the goal of furthering Serbian 
national identity. He could not help but write in 1908 in the first footnote of his work about the veneration of Saint Sava as Patron of Serbian Schools, that in the 'classic regions' of 'Old Serbia' (Kosovo) and Macedonia:

the Bulgarians commemorate today ... in their schools the all-slavonic apostles Cyril and Methodius every 11th March. With this feast, the Bulgarians are in the grip of a certain political mania. Neither the Slavonic apostles Cyril and Methodius baptised the Bulgarians, nor have they translated the Holy Scripture from Greek into 'Old-Bulgarian, but Greek Priests baptised them, having been sent from Carigrad. Learned Slavicists have long fought against this false hypothesis about Bulgarian history (Veselinović 1908:22).

The promotion of Saint Sava as Patron of Schools was one of the aims of the Saint Sava Association in Belgrade - in Macedonia, this project was in direct competition with the national projects of neighbours, which had to be delegitimised.

Yet the veneration of Saint Sava served not only in the distinction and expansion of a Serbian realm to the South East, but confronted Roman Catholic interpretations of Cyril and Methodius as apostles of the Slavs and as a means for Catholic influence, too (van Dartel 1984:71-7).

The Balkan wars and the occupation of Vardar-Macedonia by Serbian forces coincided with a Serbian appropriation of the discourse about Cyril and Methodius. In 1913, M. Bašić wrote in the 'Calendar of Resurrection':

\begin{abstract}
All this was necessary to explain, that the saints Cyril and Methodius where first of all Serbian Apostles, and then Slavonic, in a broader sense. Yet by no means were they 'Bulgarian Apostles', as they are called by the Bulgarian thieves, who have it in their blood, to steal it from others, and which have managed by money to get for this trend so-called scientists. Is it correct, to call these people by the Tatar name as Bulgarians, only because they preached the word of God in the Serbian language to the Serbian people? (Bašić 1913:55).
\end{abstract}

In this framework of remembrance of Cyril and Methodius, Macedonia could then be imagined as the 'cradle' of the Serbian people.

Thus, especially in the context of the rivalry over Macedonia, where the territories of the projected nations and their states overlapped broadly, the earlier religious and transnational remembrance became more and more secularised at the turn of the century and nationalised at the end of the 19th century.

\title{
4. Between the World Wars: from nationalisation to sacralisation
}

In Yugoslavia between the World Wars, the Brothers would become a medium to construct and enforce not only a Serbian, but a transnational Yugoslavian identity, too. For example, there was such an attempt in Macedonia in 1933 when the president of the Yugoslavian Youth Association in the Province, Ljubomir Marković, wished during a session commemorating the Brothers that his association should: 
honour the day of the saints in future every year, since Saints Cyril and Methodius are, without doubt, the spiritual Enlighteners of our nation, they have given her the possibility of prolongation of the process of civilisation, giving her the alphabet and the beginning of any science. By this, they made possible not only our cultural development, but that of all Slavdom. That's why we have to give them the first rank among the Enlighteners of the Yugoslavdom, but just behind them is Saint Sava (Jugoslovenska omladina, 1933, 1).

Ranking in the third place would be 'in the Catholic part of our people' Strossmayer. Marković continued:

Going back to the beginning of our presence here in the Balkans, we will see, that we all already then had a peculiarity of Slavic type, but we were torn and divided, we did not have a common clip, binding us strongly and unifying us. Especially here in the South, at the crossing of different cultures, we can call them uncultured [nekultura], it has been hard to build up mutual cooperation. This connection and this clip have given us the brothers Cyril and Methodius. (Jugoslovenska omladina, 1933:1).

These surprisingly openhearted sentences, published in the newspaper 'Vardar', show how deliberately Cyril and Methodius were chosen as a means to further national cohesion. Here, in contrast to older and other contemporary texts, it was no longer their aim to implant an explicitly Serbian identity, but provide a stage for a transnational, Yugoslavian cooperation. There were quite pragmatic attempts to widen the social acceptance of this concept, too - Marković linked the planned commemoration of the brothers with an excursion of the children's organisation of the Sokol Association to Skopje.

Yet this approach was not realised thoroughly, last but not least because the brothers were of much less importance for Serbian and Yugoslavian identity and its promotion in Kosovo, Macedonia and Bosnia-Hercegovina than Saint Sava. In the discourse about him, they could be seen as 'Greeks', and served to distinguish Sava's 'national' achievements (Đorđić 1935:28).

In Bulgaria, Cyril and Methodius were used in the first years after World War I to promote a national narrative toward a strategy to get back the territories lost by Bulgaria with the end of the war. Now the Brothers became part of modern nationalist ideologies - 'broad masses' should be mobilised by their 'ideals' (Sv. Sv. Kiril i Metodi 1921:3). At this time, in the competition over the identity of the population of Macedonia, a Macedonian national discourse became stronger than before. The indication, that Bulgarians were allegedly suppressed in Vardar-Macedonia, was until the end of the 1920s most prominent only in the newspapers of émigré Macedonians. But in the 1930s, this became a characteristic of the remembrance of the two brothers in an overall Bulgarian context, too. In the 1930s and 1940s, Cyril and Methodius became an important point of crystallisation of a messianic Bulgarian nationalism and were described as national 'symbols' of Bulgaria and as 'saviours' of the Bulgarian nation (P. 1932:236, Minčev 1940). 
For example, in the conception of Bishop Kiril of Plovdiv, the transnational veneration was to be removed by the national imagination of the brother's 'spirit' and by a sacralised national Bulgarian history. He described the Brothers as essence of a sacral nation, which seemed to replace traditional religion:

the all-Bulgarian soul presents itself through great figures, with deep spirits and beliefs, which conserve her unity [obviously the unity of the Bulgarian soul, S.R.] She [again the soul, S.R.] is bearing the spirit of the holy brothers Cyril and Methodius [...] and as long this is as it is, this ghost will vitalise our fate (Plovdkivskij 1940:262).

So, Cyril and Methodius played in Bulgaria a similar role to Saint Sava in the Serbian discourse - all of them were instrumentalised in the sacralisation of each national community. Yet in Bulgaria, the remembrance of Cyril and Methodius was not elaborated to a consolidated national religious ideology such as the 'Svetosavlje' (Buchenau 2006) in Serbia - although the sacralised nationalisation and militarisation of theirs and Kliment of Ohrid's remembrance culminated in the Bulgarian discourse, when they were used to legitimise the occupation of VardarMacedonia during World War II.

\section{Conclusion}

Therefore, Cyril and Methodius became within the framework of national movements important crystallisation points for national identities, although initially their traditional veneration was to a high degree Slavonic, or transnational. National identity was more and more isolated from the transnational context, until reference to other Slavonic peoples served only to demonstrate the historic importance of the mission of their 'own' nation. One can distinguish more or less clearly a secularisation of the saints in the 19th century, in the context of historicism and nationalism, while during the 1930s and World War II, they served the sacralisation of nationalism.

For this functional change of remembrance of religious figures of memory, the mutual demarcation of the developing national projects from each other was decisive - especially in the conflict over Vardar-Macedonia. The concepts were addressed to the same population of orthodox Slavs in this region from at least two directions. The concepts of the Bulgarians as well as the Serbians correlated implicitly and often explicitly in specific situational contexts. Non-orthodox minorities were mostly not mentioned in the rhetorics of the national elites on utopian ethnic homogenous territorial nation-states, and were thus excluded. The Bulgarian and Serbian conceptions evolved just in this mutual relationship and in competition between neighbours. From a transnational perspective, they have to be analysed as they evolved, as competitive memories, de-legitimising each other, and not as unique and isolated phenomena. 
Address:

Stefan Rohdewald

Lehrstuhl für Neuere und Neueste Geschichte Osteuropas und seiner Kulturen

Universität Passau

Innstr. 25

DE-94032 Passau

Germany

Tel.: 00498515092873

E-mail: Stefan.Rohdewald@uni-passau.de

\section{References}

Aleksov, Bojan (2003) "Nationalism in construction: the Memorial Church of St. Sava on Vračar Hill in Belgrade". Balkanologie 7, 2, 47-72.

Anderson, Benedict (1991) Imagined communities, reflections on the origin and spread of nationalism. Rev. ed. London and New York: Verso.

Angelov, Bonju (1969) Borba za deloto na Kiril i Metodij. Sofia.

Anzulovic, Branimir (1999) Heavenly Serbia. From myth to genocide. New York and London: New York University Press.

Assmann, Jan (1997) Das kulturelle Gedächtnis. Schrift, Erinnerung und politische Identität in frühen Hochkulturen. München: Beck.

Balabanov, Kosta (1988) "Širenjeto na kultot na slovenskite prosvetiteli Kiril i Metodij vo periodot od XIX vek". In Kirilometodievskiot (staroslovenskiot) period i kirilo-metodievskata tradicija vo Makedonija. Prilozi od Naučniot Sobir Održan po povod 1100-godišninata od Smrtta na Metodij Solunski, Skopje, 1-3 oktomvri 1985 godina, 213-217. Ed. Blaže Koneski. Skopje.

Bašić, M[ilivoje?]. "Sveti Ćirilo i Sveti Metodije, srpsko-slovenski apostoli". In Vaskrsenje. Kalendar za prostu 1914 godinu 1913, 51-63.

Brown, Keith (2003) The past in question: modern Macedonia and the uncertainties of nation. Princeton: Princeton University Press.

Buchenau, Klaus (2006) "Svetosavlje und Pravoslavlje. Nationales und Universales in der serbischen Orthodoxie". Schulze Wessel 203-232.

"Bukurešt, 18. Maija”. Nezavisimost' 19 May 1873, 35, 273-274.

Češmedžiev, Dimo D. (2001) Kiril i Metodij v bălgarskata istoričeska pamet prez srednite vekove. Sofia.

Denjat na Kiril i Metodij. Sofia, 1994.

Đorđić, Petar (1935) "Od Ćirila i Metodija ka svetome Savi”. Svetosavlje 4, 27-32.

Drumev, Vasil (1885) “6-j Aprilij 1885 god.” In Tisjaštelětnij spomen na svetite ravnoapostoli Metodija i Kirilla, prosvětiteli slavenski izdadeno po slučaj prazdnuvaneto tisjaštelětieto ot smăr'ta na Sv. Metodija 6 april 1885. god. Životat i podvizite na sv. slavjanski prosvetiteli Metodija i Kirila. Osobna priturka kăm XIV knižka ot "Periodičesko Spisanie” i na Bălgarskoto Knižovno Družestvo v Srědec, Part 1, 1-18. Sofia.

Durković-Jakšić, Ljubomir (1986) Kult slovenskih apostola Ćirila i Metodija kod Srba. Beograd.

Eastmond, Antony (2003) "'Local' saints, art and regional identity in the orthodox world after the Fourth Crusade". Speculum 78, 707-749.

Echterhoff, Gerald and Martin Saar, eds. (2002) Kontexte und Kulturen des Erinnerns. Maurice Halbwachs und das Paradigma des kollektiven Gedächtnisses. Mit einem Geleitwort von Jan Assman. Konstanz: UVK Verlagsgesellschaft.

Emmert, Thomas A.(1990) Serbian Golgotha. Kosovo, 1398. New York.

François, Etienne and Hagen Schulze (2002) "Einleitung". In Deutsche Erinnerungsorte. Vol 1, 9-24. E. François und H. Schulze, Hg. München: C. H. Beck. 
Flacke, Monika, ed. (1998) Mythen der Nationen. Ein europäisches Panorama. Berlin: Koehler \& Amelang.

Grivec, František (1927) Slovanska Apostola Sv. Ciril in Metod. Ljubljana.

Hobsbawm, Eric and Terence Ranger (1983) The invention of tradition. Cambridge: Cambridge University Press.

Hiljadugodišnja svetkovina za spomen slavenskich apostola, sv. Ćirila i Metodija. Beograd 1863.

Jugoslovenska omladina V. B. "Ćirilo i Metodije slava naše omladine”. Vardar 28 May 1933, 87, 1.

Kämpfer, Frank (1994) "Herrscher, Stifter, Heiliger. Politische Heiligenkulte bei den orthodoxen Südslaven”. Politik und Heiligenverehrung im Hochmittelalter, 423-445. Jürgen Petersohn, Hg. (Konstanzer Arbeitskreis für Mittelalterliche Geschichte. Vorträge und Forschungen, 42.) Sigmaringen: Thorbecke.

Lis, Izabela (2004) Swięci w kulturze duchowej i ideologii Stowian prawostawnych średniowieczu (do $X V$ w.), 39-67. Kraków.

Maner, Hans-Christian and Martin Schulze-Wessel, eds. (2002) Religion im Nationalstaat zwischen den Weltkriegen 1918-1939. Polen - Tschechoslowakei - Ungarn - Rumänien. Stuttgart: Franz Steiner Verlag.

Minčev, Minčo (1940) Prosvětitelitě Kiril i Metodij. Slavjanobălgarskitě spasiteli. Rajkovo.

Nitsche, Peter (2003) “'Das serbische Golgatha.' Das Kosovo als Gedächtnisort und nationaler Mythos". Gedächtnisorte in Osteuropa. Vergangenheiten auf dem Prüfstand, 139-156. Rudolph Jaworski, Jan Kusber and Ludwig Steindorff, Hg. (Kieler Werkstücke, Reihe F: Beiträge zur osteuropäischen Geschichte, 6.) Frankfurt am Main etc.: Peter Lang.

Oexle, Otto Gerhard (1995) "Memoria als Kultur". Memoria als Kultur, 9-78. Otto Oexle, ed. (Veröffentlichungen des Max-Planck-Instituts für Geschichte, 121.) Göttingen.

P. (1932)“Prazdnikăt na Slavjanskitě prosvětiteli”. Cărkoven vestnik 21 May, 21, 236-237.

Plovdkivskij, Kiril (1940) "Svetitě Bratja". Cărkoven vestnik 24 May, 22, 262.

Polenakoviḱ, H. (1963) "Beleški za kirilometodievskoto prašanje kaj Makedoncite vo XIX vek". Glasnik na Institut za Nacionalna Istorija 7, 1, 157-180.

Polyviannyj, Dmitry (1999) "The cults of saints in the political ideology of the Bulgarian Empire". Fonctions sociales et politiques du culte des saints dans les sociétés de rite grec et latin au Moyen Age et à l'époque moderne, 401-417. Marek Derwich and Michel Dmitriev, eds. Wrocław.

Rohdewald, Stefan (2007) "Sava, Ivan von Rila und Kliment von Ohrid. Heilige in nationalen Diensten Serbiens, Bulgariens und Makedoniens". Samerski 182-217.

Samerski, Stefan, Hg. (2007) Die Renaissance der Nationalpatrone. Erinnerungskulturen in Ostmitteleuropa im 20./21. Jahrhundert. Köln, Weimar und Wien: Böhlau.

Schenk, Frithjof B.(2004) Aleksandr Nevskij. Heiliger - Fürst - Nationalheld. Eine Erinnerungsfigur im russischen kulturellen Gedächtnis (1263-2000). (Beiträge zur Geschichte Osteuropas, 36.), Köln, Weimar und Wien: Böhlau.

Schulze-Wessel, Martin, Hg. (2006) Nationalisierung der Religion und Sakralisierung der Nation im östlichen Europa. Stuttgart: Franz Steiner Verlag.

Simeonova, Gatja (1993) Problemi na Kirilo-Metodievata Prazničnost. Sofia.

Smith, Anthony D. (1999) Myths and memories of the nation. Oxford: Oxford University Press.

Smith, Anthony D. (2003) Chosen peoples: sacred sources of nationali. Oxford: Oxford University Press.

Steigmann-Gall, Richard (2004) "Was national socialism a Political religion or a religious politics?". Religion und Nation. Nation und Religion. Beiträge zu einer unbewältigten Geschichte, 386408. Michael Geyer und Hartmut Lehmann, Hg. Göttingen: Wallstein Verlag GmbH.

Stroßmayer, Juraj Josip (1881) Die Heiligen Cyrill und Method. Autorisierte Uebersetzung aus dem Croatischen. (Weckstimmen für das katholische Volk, 12, 4.). Wien.

Sv. Sv. Kiril i Metodi 24/11 Maj 1921 god. Ministerstvoto na Narodnoto Prosvěštenie, ed. Sofia, 1921.

Trajanovski, Aleksandar (1995) "Čestvuvanjeto na tradiciite i kultot na svetite Kliment i Naum Ohridski vo Makedonskiot XIX vek". Svetite Kliment i Naum Ohridski i pridonesot na 
ohridskiot duhoven centar za slovenskata prosveta i kultura. Prilozi od naučen sobir održan na 13-15 septemvri 1993, 317-335. Petar Hr. Ilievski, ed. Skopje.

Troebst, Stefan (s.a.) Zwischen religiöser Tradition, kommunistischer Prägung und kultureller Umwertung: Transnationalität in den Erinnerungskulturen Ostmitteleuropas seit 1989. <http://hsozkult.geschichte.hu-berlin.de/projekte/id=154> (last seen 1 April 2007).

van Dartel, Geert (1984) Cirilometodska ideja i svetosavlje. Zagreb.

Veselinović, Milojko (1908) "Sveti Sava. Školski patron u Srba”. Brastvo 12-13, 21-133.

Vucinich, Wayne and Thomas Emmert, eds. (1991) Kosovo. Legacy of a medieval battle. (Minnesota Mediterranean and East European Monographs, 1.) Minneapolis: University of Minnesota Press.

Weber, Claudia (2006) Auf der Suche nach der Nation. Erinnerungskultur in Bulgarien von 18781944. (Studien zur Geschichte, Kultur und Gesellschaft Südosteuropas, 2.) Berlin: LIT Verlag.

Werner, Michael and Bénédicte Zimmermann (2002) "Vergleich, Transfer, Verflechtung. Der Ansatz der Histoire croisée und die Herausforderung des Transnationalen". Geschichte und Gesellschaft 28, 4, 607-636.

Xiljadogodišnij jubilej na slavjanskitě prosvětiteli Kirilla i Metodija v Sofija 885-1885. Plovdiv, 1885. 